\title{
Chapter 21 \\ Insurance as a Response to Loss and Damage?
}

\author{
JoAnne Linnerooth-Bayer, Swenja Surminski, Laurens M. Bouwer, Ilan Noy \\ and Reinhard Mechler
}

\begin{abstract}
This chapter asks whether insurance instruments, especially microinsurance and regional insurance pools, can serve as a risk-reducing and equitable compensatory response to climate-attributed losses and damages from climate extremes occurring in developing countries, and consequently if insurance instruments can serve the preventative and curative targets of the Warsaw International Mechanism for Loss and Damage (WIM). The discussion emphasises the substantial benefits of both micro-insurance programs and regional insurance pools, and at the same time details their significant costs. Beyond costs and benefits, a main message is that if no significant intervention is undertaken in their design and implementation, market-based insurance mechanisms will likely fall short of fully meeting WIM aspirations of loss reduction and equitable compensation. Interventions can include subsidies and other types of support that make insurance affordable to poor clients; interventions can also enable public-private arrangements that genuinely catalyse risk reduction and adaptation. Many such interventions are already in place, and the chapter highlights two potential success stories for insurance instruments serving the most vulnerable: the African R4 micro-insurance program and the African Risk Capacity (ARC) regional insurance pool. While support to these and other insurance programs continues to be framed as humanitarian aid based on the principle of solidarity, discussions on the G7 initiative to insure vulnerable households, as
\end{abstract}

J. Linnerooth-Bayer $(\bowtie) \cdot R$. Mechler

International Institute for Applied Systems Analysis (IIASA), Laxenburg, Austria

e-mail: bayer@iiasa.ac.at

S. Surminski

Grantham Research Institute on Climate Change and the Environment, London School of Economics and Political Science (LSE), London, UK

L. M. Bouwer

Deltares, Delft, Netherlands

e-mail: laurens.bouwer@hzg.de

I. Noy

Victoria University of Wellington, Wellington, New Zealand

L. M. Bouwer

Climate Service Center Germany (GERICS), Hamburg, Germany

(C) The Author(s) 2019

R. Mechler et al. (eds.), Loss and Damage from Climate Change, Climate Risk

Management, Policy and Governance, https://doi.org/10.1007/978-3-319-72026-5_21 
well as on ARC's initiative to link international payments to climate risks, raise the question whether the narrative will evolve from solidarity to responsibility based on the principle of developed country accountability.

Keywords Risk transfer $\cdot$ Financial instruments $\cdot$ Climate change $\cdot$ Catastrophic loss $\cdot$ Safety nets $\cdot$ Disaster risk reduction $\cdot$ Equity $\cdot$ Liability $\cdot$ Compensation

\subsection{Introduction}

Insurance has played a central role in discussions on adapting to the impacts of climate change, dating back to the early 1990s, when the Alliance of Small Island States (AOSIS) proposed a global insurance fund to compensate small islands for sealevel rise (see introduction by Mechler et al. 2018). Taking stock of this history, as well as the accumulated experience with catastrophe insurance instruments, this chapter asks if insurance mechanisms can help serve the intent of the Warsaw International Mechanism for Loss and Damage (WIM) and Article 8.1 of the Paris Agreement of 'averting, minimising and addressing loss and damage associated with the adverse effects of climate change, including extreme weather events and slow onset events..." (UNFCCC 2015, Article 8). The focus is on weather and climate extremes, including droughts, floods, windstorms and other hazards impacted by anthropogenic climate change, which occur in particularly vulnerable developing countries.

Although the precise intentions of the WIM are still unclear, and especially its distinction from climate adaptation (see chapters by Mechler et al. 2018; Schinko et al. 2018), the WIM Executive Committee (2016) emphasises the role of insurance in furthering climate risk management, or more specifically its role in proactively reducing and transferring risks. In addition, and importantly, discussions on Loss and Damage (L\&D) and the WIM have extended to adaptation limits and 'beyond adaptation“ (Schäfer et al. 2018). According to the UNFCCC, loss and damage "includes, and in some cases involves more than, that which can be reduced by adaptation" (Decision 2/CP.19, UNFCCC 2014). This has been interpreted by many WIM commentators, and especially developing country parties, to suggest compensation for climate-attributed losses and damages experienced by the most vulnerable communities (see Mace and Verheyen 2016). A legal obligation to compensate for residual loss and damage (the climate-attributed losses and damages that remain once all cost-effective and socially/politically feasible measures have been implemented (UNFCCC 2012) is ruled out in the Paris Agreement (Paragraph 52), yet not for the broader debate, where residual losses and damages resulting from climaterelated extremes raise ethical issues concerning retribution or (non-legally binding) compensation (see also Simlinger and Mayer 2018). In line with the discussion in Mechler and Schinko (2016) and the chapter by Schinko et al. (2018) we refer to risk reduction and (non-legally binding) compensation as preventative and curative responses, respectively, and explore the role of insurance instruments in promoting these responses. 
In simple terms, insurance allows one party (the insured or policyholder) to transfer the risk of future economic losses to a second party (the insurer) willing to bear this risk for the payment of a premium. By transferring the risk ex ante, insurance clients are guaranteed payments for the agreed upon losses and damages from events ex post. In this way insurance, as one of a number of risk financing instruments, provides reimbursement in return for the payment of a premium such that households, businesses, governments and whole regions can recover in a timely way from the damages from extreme events. In addition, many argue that insurance goes beyond post-disaster reimbursement to pro-actively prevent damages from occurring (see chapter by Schäfer et al. 2018). By 'pricing' risk and requiring preventative measures, insurance provides (in theory) incentives or conditions for clients to adopt damage-reducing behaviour and make investments to reduce their risks.

Insurance thus appears to serve the goals of disaster risk reduction (DRR) as well as post-disaster reimbursement. If insurance payouts are viewed as compensation for losses and damages, insurance serves as a preventative and curative instrument, therefore responding to WIM aspirations as (differently) voiced by developed and developing country parties (see chapter by Calliari et al. 2018). It is not surprising, then, that insurance has figured so prominently in the L\&D discussions and work plan. However, while these insurance characteristics have motivated the discussions on insurance as a tool to address climate-attributed losses and damages, they raise questions essential to the WIM deliberations. Most fundamentally, can insurance be viewed as an equitable curative measure for climate-attributed impacts and risks incurred by poor communities in vulnerable countries? This in turn raises questions concerning burden sharing: How are premiums determined and who pays them? Another central question concerns the disaster-risk-reduction (DRR) potential of insurance. Are insurance instruments, as they are currently practiced, effective in encouraging prevention and risk reduction by incentivising or requiring adaptation and resilience investments?

By examining these and other questions, this chapter explores the extent to which insurance-provided through private markets or public institutions - can meet the differentiated WIM ambitions of reducing and compensating for Loss and Damage. The discussion focuses on recent evidence from micro-insurance and regional sovereign insurance pools as these are the most common types of catastrophe insurance currently operating in developing countries, which has given them a particular standing the L\&D discussions.

After an overview of catastrophe insurance and its role for loss and damage from climate change (Sect. 21.2), the discussion turns to the benefits and costs of insurance (Sect. 21.3), before it examines insurance as a tool for preventing the economic impacts from extreme weather events (Sect. 21.3) and for reimbursing the residual loss and damage (the curative aspect) (Sect. 21.4) with examples from micro-insurance programs and regional insurance pools. The chapter concludes (in Sect. 21.5) that insurance instruments based on the 'mutuality principle' (premiums reflect risk plus markup or 'load') will fall short of meeting the 'preventative' and 'curative' aspirations underlying the WIM and Paris Agreement; however, insurance 
based on the 'solidarity' and 'accountability' principles accompanied by significant outside interventions can indeed support WIM objectives.

\subsection{Insuring Climate Risks: An Overview}

\subsubsection{Brief History}

Reference to insurance was first made by the Alliance of Small Island States (AOSIS), which suggested in 1991 that an international insurance pool funded by industrialised parties be established to compensate small-island and low-lying developing nations for impacts resulting from sea level rise (INC 1991; chapter by Mechler et al. 2018). The insurance mechanism proposed by AOSIS was not aimed at establishing private sector risk transfer, but geared towards a compensation fund to address L\&D from sea level rise. As such, it was not strictly insurance in a technical sense, but a compensation mechanism (Linnerooth-Bayer et al. 2003). What remained from these early discussions is reflected in Article 4.8 of the UNFCCC, which calls upon Parties to "consider" actions, including those related to insurance, to meet the specific needs and concerns of developing countries with respect to the adverse impacts of climate change (United Nations 1992). In subsequent years, AOSIS as well as other organisations, such as the Munich Climate Insurance Initiative (MCII), developed proposals for the use of insurance mechanisms to address climate change impacts and risks (AOSIS 2008; MCII 2008). Notably, both the AOSIS and MCII proposals brought a compensatory or curative mechanism for loss and damage in through the back door by including a risk layer in the insurance arrangement that would be fully financed by developed countries; although not differentiating between climatechange attributed impacts and other risk drivers. In addition, both proposals called for increased financing for DRR projects as part of a holistic climate risk management approach. The proposals informed the negotiating text at COP 15 in Copenhagen in 2009, and went on to influence negotiations on the L\&D mechanism at COP 19 in Warsaw in 2013. Subsequently, insurance has featured prominently on the WIM agenda, most notably on the workplans of the WIM executive committee (ExCoM) (UNFCCC 2014, 2016).

Recognition of insurance as a potent response to climate risk has been subsequently underscored by the G7 InsuResilience initiative, and recently upgraded to the G20 and V20 partnership (most vulnerable 20 countries), which ambitiously aims at insuring 400 million currently uninsured people in vulnerable countries by 2020 (G7 2015; InsuResilience 2017). Interestingly, these efforts to enhance the role of insurance in addressing disaster and climate risks in developing countries occur predominantly outside the UNFCCC's L\&D discussions and are increasingly presented as part of broader development support. 


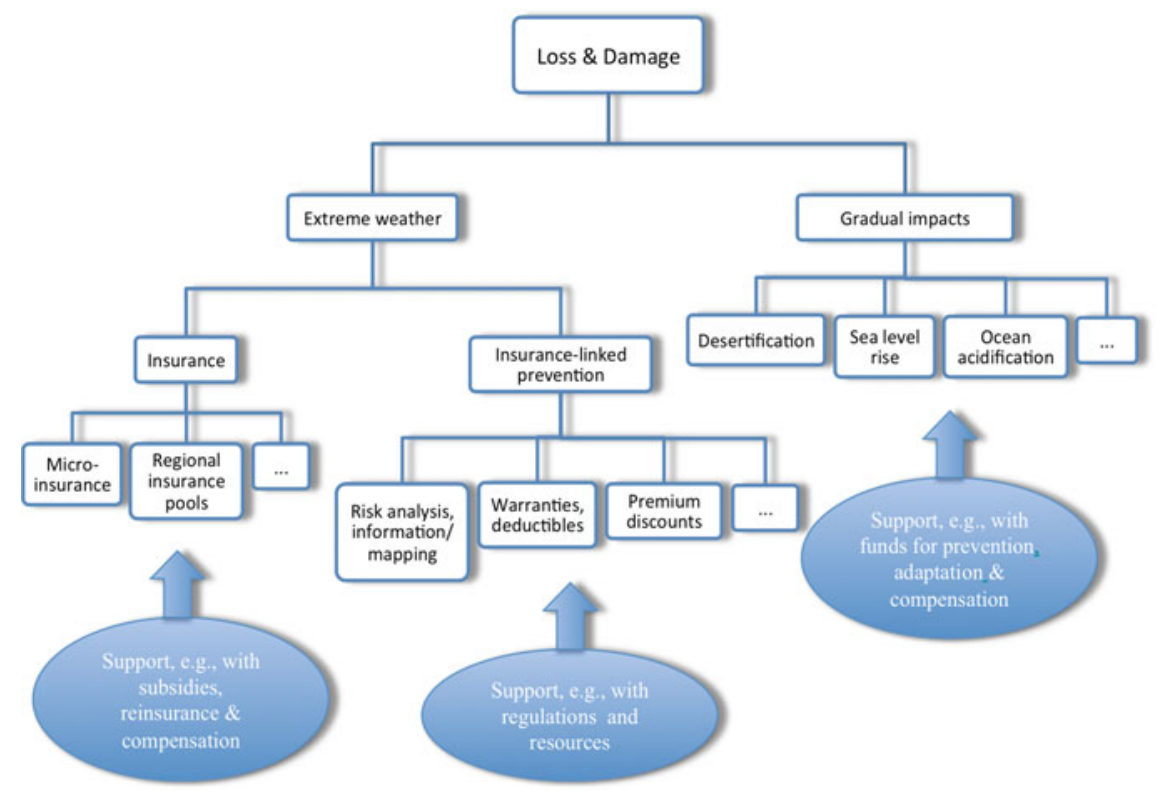

Fig. 21.1 Overview of 'risk management applications' of insurance, in the context of loss and damage . Adapted from Warner et al. (2012)

\subsubsection{Can Insurance Cover All Loss and Damage from Climate Change?}

It should be emphasised that insurance cannot provide financial protection against all impacts from climate change (Warner et al. 2009). As shown in Fig. 21.1 insurance is an instrument for financing the recovery from extreme and non-gradual climate events, like floods, windstorms and droughts, but is not suited for managing the damage caused by slow-moving or gradual changes that include, among other impacts, sea-level rise, desertification, loss of habitat, loss of biodiversity, erosion, ocean acidification and glacial retreat (chapter by Bouwer 2018). At the same time, these slow climatic changes can become manifest through insurable rapid-onset events, for example, sea-level rise exacerbates storm surge levels and coastal flooding. Equally difficult to insure are small-scale events for which damages are mostly expressed in the cumulative wear-and-tear of assets and infrastructure (Moftakhari et al. 2017). Insurance thus has clear limitations, as it can only cover those events that are sufficiently random and infrequent in their occurrence. Finally, as shown in Fig. 21.1, the range of loss events (rapid-onset to gradual) is accompanied by a range of policy support instruments for risk reduction or reimbursing impacts-from support for insurance instruments (e.g., public subsidies or reinsurance) or insurance-linked prevention, to reparations for gradual onset impacts. 


\subsubsection{Spectrum of Ex Ante and Ex Post Financing Instruments}

Insurance is not the only measure to ensure post-disaster financial resources, and in some contexts other mechanisms can be more appropriate and cost-effective. It is therefore important not to view insurance as a stand-alone solution but consider if and how it can be part of a holistic climate risk management approach. In contrast to wealthy countries, insurance mechanisms for providing catastrophe cover are still in their infancy in the developing world. The percentage of losses from natural hazards covered by private or public insurance in 2014 in the US and Europe were 42 and $34 \%$, respectively, compared to only $1.4 \%$ in Africa and $12.5 \%$ in Asia (Swiss Re 2015). The extent to which insurance can be offered is risk and country-specific and dependent mainly on income.

Table 21.1 provides an overview of financial instruments and arrangements available to cover disaster risks facing (i) households, farms and small and medium sized enterprises (SMEs) operating at the local or micro scale, (ii) financial- and donororganisations operating at the intermediary scale, and (iii) governments operating at the national or macro scale.

Table 21.1 Examples of risk financing arrangements at micro, intermediary and macro scales

\begin{tabular}{|c|c|c|c|}
\hline & $\begin{array}{l}\text { Micro-scale } \\
\text { Households/SMEs/Farms }\end{array}$ & $\begin{array}{l}\text { Intermediary-scale } \\
\text { Insurers/financial } \\
\text { institutions/donor } \\
\text { organisations/NGOs/Agro- } \\
\text { Businesses/Cooperatives }\end{array}$ & $\begin{array}{l}\text { Macro-scale } \\
\text { Governments }\end{array}$ \\
\hline $\begin{array}{l}\text { Insurance } \\
\text { instru- } \\
\text { ments }\end{array}$ & $\begin{array}{l}\text { Indemnity-based } \\
\text { property, crop \& life } \\
\text { insurance, index-based } \\
\text { (parametric) property, } \\
\text { livestock \& crop } \\
\text { insurance, weather } \\
\text { hedges, national insurance } \\
\text { programs }\end{array}$ & $\begin{array}{l}\text { Indemnity and parametric } \\
\text { insurance for NGOs, } \\
\text { co-ops, Re-insurance for } \\
\text { direct insurance providers, } \\
\text { catastrophe bonds, } \\
\text { sidecars }\end{array}$ & $\begin{array}{l}\text { Sovereign risk transfer } \\
\text { (e.g., sovereign } \\
\text { re-insurance, catastrophe } \\
\text { bonds, sidecars), } \\
\text { contingent credit, regional } \\
\text { catastrophe insurance } \\
\text { pools }\end{array}$ \\
\hline Solidarity & $\begin{array}{l}\text { Government assistance, } \\
\text { humanitarian aid }\end{array}$ & $\begin{array}{l}\text { Government } \\
\text { guarantees/bail outs }\end{array}$ & $\begin{array}{l}\text { Bi-lateral and multi-lateral } \\
\text { assistance, EU solidarity } \\
\text { fund }\end{array}$ \\
\hline $\begin{array}{l}\text { Savings } \\
\text { and credit }\end{array}$ & $\begin{array}{l}\text { Savings, micro-savings, } \\
\text { micro-credit, fungible } \\
\text { assets, food storage, } \\
\text { money lenders }\end{array}$ & Emergency liquidity funds & $\begin{array}{l}\text { Reserve funds, } \\
\text { post-disaster credit }\end{array}$ \\
\hline $\begin{array}{l}\text { Informal } \\
\text { risk } \\
\text { sharing }\end{array}$ & $\begin{array}{l}\text { Kinship and other mutual } \\
\text { arrangements, remittances }\end{array}$ & & $\begin{array}{l}\text { Diversions from other } \\
\text { budgeted programs }\end{array}$ \\
\hline
\end{tabular}

Source Adapted from Linnerooth-Bayer et al. (2010) 
Lacking insurance, vulnerable households and other local actors have traditionally financed post-disaster recovery with a combination of savings and credit, informal kinship arrangements, government relief and international donor support. Savings can take the form of stockpiles of food, grains, seeds and marketable assets, which serve to smooth consumption during crises. The most common form of assistance is remittances, which are more than three times the size of official development assistance (World Bank 2016), and can be a significant contribution to postdisaster recovery. Banks, insurers and other monetary financial institutions (MFIs), as intermediary-scale actors, can also protect their post-disaster liquidity by purchasing reinsurance, relying on bail outs from the government, or support from institutions like the African Emergency Liquidity Facility (OMTRIX 2005) or the World Bank.

Governments as national operators can meet their obligations to repair public infrastructure and support needy households with ex post and ex ante instruments. Typically, and as detailed in Table 21.2, public authorities seek financing after disasters occur, for instance, by issuing tax increases, re-allocating funds from other budgeted activities, or borrowing through issuing bonds. Governments of highly exposed countries may also rely on assistance from the international community. An example of the latter is the significant support provided by the World Bank, and in Europe the European Union Solidarity Fund provides post-disaster support to governments to support their recovery (Hochrainer-Stigler et al. 2017).

In addition to these ex post instruments, governments increasingly anticipate disaster events with ex ante financing or risk transfer as shown in Table 21.2. Risk financing at sovereign level includes a wide range of tools such as national reserve funds, sovereign insurance (also offered through regional pools), and credit and capital market products, such as catastrophe bonds, where bond purchasers agree to forfeit interest or principle if a pre-defined hazard or disaster occurs (see Cardenas et al. 2007). Such a catastrophe bond (150 Million USD), for example, was triggered by the 2017 Oaxaca earthquake (ARTEMIS 2017b). Insurers make use of other types

Table 21.2 Financing instruments for protecting government budgets

\begin{tabular}{l|l|l}
\hline \multicolumn{2}{l}{ Financial and budgetary instruments } \\
\hline Goal & $\begin{array}{l}\text { Ex ante instrument } \\
\text { [arranged before a disaster] }\end{array}$ & $\begin{array}{l}\text { Ex post instrument } \\
\text { [arranged after a disaster] }\end{array}$ \\
\hline $\begin{array}{l}\text { Risk retention } \\
\text { [changing how or when one } \\
\text { pays] }\end{array}$ & $\begin{array}{l}\text { Contingency fund or } \\
\text { budget allocation }\end{array}$ & Budget reallocation \\
\cline { 2 - 3 } & Line of contigent credit & Tax increase \\
\cline { 2 - 3 } $\begin{array}{l}\text { Risk transfer } \\
\text { [removing isk from the } \\
\text { balance sheet] }\end{array}$ & $\begin{array}{l}\text { Traditional insurance or } \\
\text { reinsurance Indexed insurance, } \\
\text { reinsurance, or derivatives }\end{array}$ & $\begin{array}{l}\text { Discretionary post-disaster } \\
\text { relief }\end{array}$ \\
\cline { 2 - 2 } & Capital market instruments & \\
\hline
\end{tabular}

Source Clarke and Dercon (2016) 
of alternative instruments, such as reinsurance sidecars, where investors act directly as reinsurers, and risk swaps, options and loss warranties. Most of these alternative instruments provide an opportunity for investors in the capital markets to take a more direct role in providing insurance and reinsurance protection.

\subsubsection{Types of Insurance}

Insurance, whether for health, unemployment or climate-related disasters, is a central feature of most wealthy countries; yet, institutional arrangements can differ significantly depending particularly on the degree of private-market responsibility. In this discussion, we distinguish between private-market insurance, public-private insurance arrangements, and public assistance. Private-market insurers underwrite the risks, and clients are asked to pay their full or close-to-full risk-based premium, albeit often with cross-subsidies from low-risk to high-risk clients that keep the premiums affordable (e.g., flood insurance in Germany, Norway and the U.K.). At the other end of the spectrum is public assistance, which can take the form of a catastrophe reserve fund financed from general taxes (e.g., in Austria) from which loss reimbursement can be legally binding (e.g., earthquake relief in Italy) or non-legally binding and ad hoc (e.g., in Hungary). In between these two ends of the spectrum are many public-private arrangements. Public institutions are active, for instance, in underwriting insurance (e.g., the US National Flood Insurance Program), providing subsidies and other support to private insurance programs (e.g., the Austrian crop insurance system), or supporting commercial insurers with reinsurance arrangements (e.g., the French all-hazard insurance system).

Insurance can be indemnity-based, where products are written against actual losses, or parametric, where products are written against a physical index (e.g., soil moisture), that is, against events that cause loss, not against the loss itself. A parametric instrument disburses funds based on a triggering event that reaches a pre-determined threshold of a quantifiable measure (for example, wind speed or precipitation), which importantly is not conditional on an on-site loss assessment. Semi-parametric schemes are also written, where the trigger is a combination of a hazard and its calculated/modelled impact based on known exposures and vulnerabilities (Molini et al. 2007).

Because they target the most vulnerable in the developing world and have featured prominently in the L\&D discussions, two types of insurance are highlighted in this chapter: (1) micro-insurance that offers cover to households, farms and SMEs, and (2) regional sovereign risk pools providing support for national governments. The intent of micro-insurance is to make insurance accessible by avoiding the high costs of traditional insurance in order to service resource-poor markets, usually by offering limited cover and greatly reducing transaction costs (Mechler et al. 2006). The intent of regional sovereign risk insurance pools, including those already formed in the Caribbean, Pacific Islands and Africa, is to ensure needed and timely liquidity postdisaster. 


\subsection{The Benefits and Costs of Insurance}

\subsubsection{Benefits of Insurance}

The central feature of insurance is its risk-pooling capacity. By pooling risks from a sufficiently large and independent number of individual households, farms, businesses and even sovereign states, insurance collectively reduces loss volatility (mathematically speaking, the variance of losses) and in this way can guarantee postdisaster liquidity to those individuals at risk (Kunreuther 1998). The assurance of post-disaster liquidity, in turn, can reduce impacts, including disaster-induced bankruptcy, hunger, selling of productive financial assets or taking kin out of school with long-term impacts on human capital formation. If correctly implemented insurance thus delivers risk pooling over space and time; faster and more efficient reconstruction; certainty about post-disaster support; and can reduce immediate welfare losses and consumption reductions (Brainard 2008; von Peter et al. 2012).

An important advantage of insurance over many other types of risk financing is the timeliness of the post-disaster payments. A study by Clarke and Hill (2013) suggests that rapid payouts and prompt assistance to affected populations can reduce the impact of disasters and enable poor and vulnerable people to recover more quickly. Examining experience of pro-poor insurance instruments shows that they have been an effective risk management tool in terms of providing timely payments post-event (Arent et al. 2017). Moreover, an insurance contract can be a more secure and timely means of coping with disasters than dependency on ad hoc and often delayed generosity of governments and donors. To add to these benefits, insurance can render clients more creditworthy, and in so doing promote investments in productive assets and higher-risk/higher-yield activities, in turn reducing disaster-related poverty traps (Hallegatte et al. 2016).

Turning to governments, sovereign disaster risk financing instruments including insurance pools aim at protecting public budgets in the wake of disasters. Due to limited tax bases, high indebtedness and low uptake of insurance, many highly exposed developing countries cannot fully recover by simply relying on limited external donor aid. Ex post liquidity through insurance enables governments to provide relief to the most vulnerable and to invest in reconstruction and recovery, thus reducing longterm losses and development setbacks from disasters. Sovereign risk transfers can also indirectly benefit households and other victims of disasters. With internationally backed risk-transfer programs, developing country governments will rely less on debt financing and international donations, and assured funds for repairing critical infrastructure can attract foreign investment. Finally, and importantly, insurance instruments may provide incentives to reduce risk (Newsham et al. 2011; Heltberg et al. 2009a, b), but only if they do not encourage behaviour that neglects to reduce risks in a cost-effective way, a common concern in insurance applications often referred to as 'moral hazard.' The preventative capacity of insurance instruments is the topic of Sect. 3, where we examine their risk-reduction potential in practice. 


\subsubsection{Costs of Insurance}

While there are substantial benefits provided by privately or publicly offered insurance, the costs of insurance are considerable. The average financial cost of insurance generally surpasses average losses, meaning that un-subsidised insurance premiums are greater than what the client expects to lose. For this reason, clients should carefully consider the costs and benefits, and rely on insurance only after considering the alternatives, or in the words of Vaughan and Vaughan (2008, p. 62), only as a last resort. Indeed, without outside subsidies and other forms of support policyholders can expect, on average, a higher financial burden in the long run with insurance than without it. That insurance results, on average, in greater costs to those insured is often not appreciated and needs further explanation.

The insurance premium tends to be inflated above the 'actuarially fair value' or 'pure premium' (expected losses) due to the fact that on top of the annual expected losses a risk premium is charged. As shown in Fig. 21.2, the risk premium is determined by two factors: expense load and risk load (Pollner 2000). Additionally, in the case of private insurance a profit margin is charged. In general terms the expense load reflects the costs of the insurer doing business, and the risk load includes the cost of holding capital, reinsurance and of assuming uncertain contracts for high-level risks. The risk load distinguishes catastrophe insurance from other types of insurance, like life and health, since insurers covering catastrophic risks must be prepared to pay claims for disasters that affect whole regions or countries at the same time (co-variate risk). Still, if insurers are sufficiently diversified, the risk load will not only insulate them from large losses at one time, but will also in the long run result in significant profits.

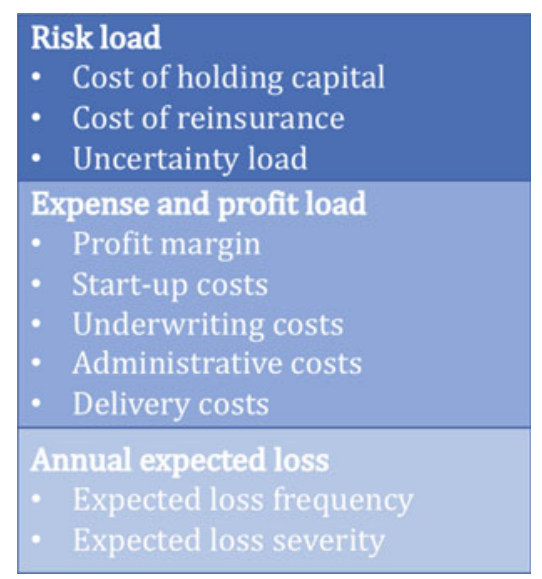

Fig. 21.2 Costs contributing to catastrophe insurance premium Source Adapted from Cummins and Mahul (2009) 
The ratio of the premium paid versus the coverage obtained gives an indication of the insurance cost, particularly when comparing insurance to other risk financing tools. Using this ratio, Ghesquiere and Mahul (2010) found that risk transfer is very costly compared to most other financial instruments (Ghesquiere and Mahul 2010; Clarke and Dercon 2016). As a case in point, in the Caribbean region annual insurance premiums (paid mostly by businesses) were estimated to represent about $1.5 \%$ of GDP during the period 1970-1999, while average losses per annum (insured and uninsured) accounted for only about $0.5 \%$ of GDP (Auffret 2003).

If insurance premiums cost clients on average more than their anticipated losses, and in the case of co-variant catastrophic events significantly so, why do households, businesses and governments insure? This question is particularly pertinent for resource-poor households and governments, where premium payments can have high opportunity costs. The textbook rationale for purchasing insurance, verified by evidence on insurance penetration, is based on the concept of "risk aversion". Riskaverse persons and entities (generally people who cannot cope with large losses) are willing to pay more than they expect to lose on average to avoid catastrophic losses. Households and farms in developing countries are likely to be highly risk averse since large losses can threaten livelihoods and lives (and thus have severe costs and other implications beyond the sheer financial loss). The same holds for the public sector since disasters can significantly affect development if governments do not have the means for rapid reconstruction and relief efforts (Mechler 2004).

For middle- to high-income earners in developed as well as developing countries an insurance value proposition can often be discerned as shown by substantial insurance demand, yet it is pertinent to ask how insurance mechanisms can serve resource-poor clients facing high risk? As current programs demonstrate, insurance premiums are made affordable by targeting higher income clients, implementing cross subsidies, limiting coverage, providing outside support and forming partnerships (Linnerooth-Bayer et al. 2010). Whereas most discussions focus largely on making insurance affordable, it should be recognised that it may not be advisable from a benefit-cost perspective. Indeed, reliance on alternative financial arrangements, like donor solidarity, savings, credit and remittances, can be considerably less costly than insurance, and these arrangements can work reasonably well for low-loss events (Cohen and Sebstad 2003). However, they can be unreliable and inadequate for covariate and catastrophic shocks that place a significant financial strain on whole communities, regions and governments. Insurance theory and recent cost-benefit assessments indicate that insurance and other risk financing instruments are mainly advisable, and viable, for large and residual risks that cannot be reduced or retained otherwise. 


\subsection{Preventative Response: Does Insurance Support the Risk-Reduction Response to the WIM?}

Many analysts argue that insurance can go beyond enabling ex post relief, reconstruction and recovery, to be an ex ante tool for promoting risk reduction (Kunreuther 1996; Kunreuther and Michel-Kerjan 2009; Crichton 2008; Botzen 2013). According to the chapter by Schäfer et al. (2018): "Insurance spurs transformation by helping countries reshape the way risks are managed. It does so by encouraging risk reduction, catalysing risk assessment, and driving more structured decision-making around ex-ante risk". Despite these claims, some commentators, including NGOs and parties to the UNFCCC, remain sceptical that insurance goes beyond risk spreading to risk reduction, and worry that insurance can even lead to a false sense of security or moral hazard if the insured, by not bearing the full costs of risky decisions, take on more risk (Vellinga et al. 2001; UNFCCC 2008). Moral hazard is widely recognised, and insurers address it through the design of insurance products by using deductibles or parametric products; however, questions remain whether insurance products lead directly to risk reduction. According to the Intergovernmental Panel on Climate Change (IPCC), insurance can "directly provide incentives for reducing risk, yet the evidence is weak and the presence of many counteracting factors often leads to disincentives..." (Chambwera et al. 2014).

Building on Surminski and Eldridge (2015) and Surminski (2014), Lorant et al. (forthcoming) identify ways in which the contractual elements and ancillary mechanisms of insurance can (in concept) encourage risk reduction. After surveying the developed-country practices of flood insurers, the authors note the disappointing evidence of a strong link between insurance and DRR and suggest ways that insurers can contribute more effectively, for example, making better use of hazard maps, monitoring household risk improvements, rewarding risk mitigation with premium discounts, inserting conditions or warranties into contracts, and developing protocols that will better link risk inspections of large facilities with underwriting practices. Beyond these design changes, there is evidence that public insurers invest more in preventative risk reduction than their private insurer counterparts (Schwarze and Croonenbroeck 2017; Ungern-Sternberg 1996). The evidence on the insurance-DRR link for the on-going work under the WIM is that indemnity-based insurance as practiced in wealthy countries may need adapting if it is to be applied as an instrument to foster reduction of loss and damage in developing countries. A similar conclusion was reached by the IPCC, where authors confirmed that risk-financing mechanisms contribute to increasing resilience, but that major design changes would be needed to avoid providing disincentives for DRR (Chambwera et al. 2014). As we witness in wealthy countries, progress will be slow and patchy without public and private commitment to shaping insurance systems such that they foster practices that lead to investment in disaster risk reduction practices. 


\subsubsection{The Experience of Micro-insurance in Promoting Risk Reduction}

The message that insurance practices will require reform if they are to better promote risk reduction holds not only for indemnity-based systems in wealthy countries, but also for parametric micro-insurance systems that are increasingly targeting resourcepoor clients in the developing world (for reviews, see Linnerooth-Bayer et al. 2012; Mechler et al. 2006; Schäfer and Waters 2016). Already in 2010, there were a reported 36 parametric weather insurance programs, including 28 addressing individual farmers/herders, residents of informal settlements, village or cooperative risk (Hazell et al. 2010), with many other programs having appeared since then (Schäfer and Waters 2016).

Parametric systems are notable for the absence of moral hazard. The insured remain motivated to reduce their losses and damages because insurance disbursements, if they are triggered, are not based on actual losses. For example, a farmer with a parametric insurance contract, which pays out if rainfall falls below a predefined level, can gain doubly by planting drought-resistant crops since the farmer will have less losses and still receive a pay-out. Beyond the elimination of moral hazard, the literature on parametric micro-insurance makes little reference to specific risk-reduction requirements, for example, in the form of conditions or warranties, and there are few accounts of micro-insurers informing clients of hazards or advising them on risk-reduction activities.

One notable positive exception is the R4 Rural Resilience Initiative (R4) that offers micro-insurance for drought risk to food-insecure communities in Ethiopia, Senegal, Malawi and Zambia (see Box 21.1). R4 currently reaches over 40,000 farms through a combination of its four risk-management strategies: The first, R1, promotes improved resource management (risk reduction); R2 supports microcredit (prudent risk taking;); R3 is insurance (risk transfer); and R4 is savings (risk reserves). The most unique and interesting feature of this initiative is its direct link to the reduction of crop loss from drought. In lieu of paying aa premium, cash-constrained farmers can opt to participate in an insurance-for-assets (IFA) plan, whereby they pay the premium through their labour on projects that reduce risk in the community, such as field irrigation projects and tree planting (World Food Programme and Oxfam America 2016). It should be noted, however, that the R4 Program operates with generously subsidised premiums, even to those not participating in insurance-forassets, and cannot be compared to a market-based insurance program.

$R 4$ is exemplary by providing a proven insurance system design that promotes $D R R$, especially since the risk management experiences of most micro-insurance programs suggest that they could become a more powerful DRR tool with carefully designed interventions by governments or donors. Importantly, the ability of those most vulnerable to reduce their own risk and to change their behaviour may be very limited or not feasible unless supported by donors. 


\section{Box 21.1 R4 Rural Resilience Initiative for drought risk management}

Countries: Ethiopia, Senegal, Malawi, Zambia

Partners: farmers, local relief society, insurers, reinsurers, rural banks, university, government and donors

Policy holders: 40,000 Smallholder farmers' livelihoods in drought-prone regions with a sum insured of USD 2.2 million, premiums of USD 370,000, and payouts USD 450,000 (2015)

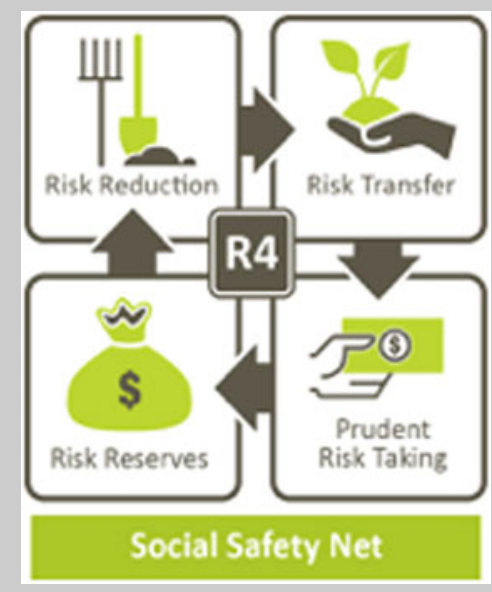

Fig. 21.3 The R4 Rural Resilience Initiative

\section{Integrated risk management framework}

- Improved resource management (risk reduction)

- Individual/group savings (risk reserves)

- Microinsurance (risk transfer)

- Microcredit (risk taking)

Insurance-for-work program to supplement the government's "food and cash for work" Productive Safety Net Programme (PSNP)

Work program includes projects for reducing risk and building climate resilience, such as improved irrigation or soil management.

Source World Food Program \& Oxfam America 2016; World Food Programme 2017

\subsubsection{The Experience of Regional Risk Pools in Promoting Risk Reduction}

The first of three regional sovereign risk pools, the Caribbean Catastrophe Risk Insurance Facility (CCRIF), was created in 2007 as a multi-government disaster risk pooling arrangement with the aim of providing sovereign insurance coverage for 
hurricanes and earthquakes to its participating member countries (UNISDR 2017). A second regional pool, Africa Risk Capacity (ARC) was established in 2012 as a specialised agency of the African Union to help member states improve their capacities to better plan, prepare and respond to natural disasters (Wilcox 2014). Recently, a third regional sovereign risk pooling arrangement has been created for the Pacific island states, the Pacific Catastrophe Risk Assessment and Financing Initiative (PCRAFI) (World Bank 2017). In all three cases, disbursements from the pool go to participating governments for the purpose of supporting their post-disaster relief and reconstruction efforts, although only one of the pools (ARC) makes requirements on how the disbursements are used by requesting its members to provide details about contingency management and disbursement when they join the pool.

A key feature of all three pools is the parametric nature of the insurance contract, which, as discussed for micro-insurance, makes payments faster and the claim process less costly than traditional indemnity-based insurance products for which claims are paid based on assessments of loss through on-site verification. Fast payment of claims is especially critical. Intervening quickly after a disaster can provide governments with funds that support households and prevent the adoption of damaging coping strategies (such as selling off or slaughtering livestock). A benefit-cost analysis carried out on the ARC shows that getting aid to households in the critical three months after harvest can result in economic gains of over USD 1,200 per household assisted (Clarke and Hill 2013). CCRIF announced that its payouts to Caribbean governments due to the impacts of Hurricane Irma, which devastated many island states in September 2017, will reach $\$ 31.2$ million, and the facility has now passed $\$ 100$ million of payouts to members since its launch. All of the $\$ 100$ million of payouts were made to members within 14 days of the catastrophe events that triggered their parametric insurance policies (ARTEMIS 2017a).

Advancing ex ante risk management is also important in all three regional programs, especially with respect to developing the knowledge base on which disaster risk reduction and management policy can be pursued. Each pool makes an effort, paid for by donors, to measure and quantify disaster risk in the relevant region by examining not only the hazard but also exposure and vulnerability using detailed mapping, data and modelling tools developed explicitly for this purpose. An example is ARC's modelling platform called African Risk View. It provides modelling input to ARC for insurance purposes, but also aims to be a financial early warning tool, supporting government decision-makers with cost estimates before and during a drought season. As such it can trigger early action and risk reduction measures. The models and quantification of risk constitute major progress as private markets and the governments of the region were not supplying this information previously. If combined with technical assistance and capacity building these advances in risk information can lead to a culture of risk management across governments, potentially inducing a more anticipatory approach to risk (Vivid Economics et al. 2016).

ARC is currently preparing for the launch of an additional tool, the Extreme Climate Facility (ARC-XCF), which aims to address adaptation and resilience shortfalls in African countries in the face of climate change. XCF is designed to take account of increasing risk of extreme weather event activity in order to disperse funds to be 
used to invest in risk-reduction activities (Wilcox 2014, see Box 21.3). This tool, requested by $\mathrm{ARC}$ member countries, offers an interesting approach to linking the risk transfer structure of ARC to climate adaptation and risk reduction investment.

Notwithstanding the paramount importance of assessing risks to countries in the pool and providing timely post-disaster funds, the regional pools have put into place very few explicit incentives or funds for reducing disaster risks. There are some requirements with regard to usage of pay-outs and emergency management, yet as shown in the case of ARC, there are no conditions for proven disaster and climate risk reductions. CCRIF has a disaster risk management function, but it focuses on reducing downstream losses after a disaster has occurred by providing immediate liquidity. In practice, then, beyond the data collection and modelling aspects (though only the ARC provides open source risk data), there is very little evidence that the regional pools shape DRR and climate adaptation policy in their member countries.

To conclude, it appears that more can be done to design regional sovereign risk pools that contribute to the preventative aspiration of the WIM, although the proposed ARC XCF offers an interesting proposition for this purpose. Design reform of the pools might include a requirement for detailed contingency plans for pre-disaster risk reduction and (in the case of CCRIF and PCRAFI) making risk data open source. The implementation of these plans could be made a requisite for continued membership in the pool.

\subsection{Curative Response: Does Insurance Promote the Equitable Compensation Response T the WIM?}

The WIM extends beyond aspirations for disaster risk reduction to include climateattributed loss and damage that cannot be effectively reduced. This has raised aspirations especially among highly vulnerable developing countries that a form of (legally non-binding) compensation for residual climate impacts may be in the offing. The question in this section is whether insurance, by reimbursing loss and damage from climate disasters, contributes to the 'equitable compensation' or curative aspirations for the WIM?

At the outset, it is worth emphasising that financial instruments, including insurance, are not neutral as to how disaster costs are shared. Risk-based instruments that require premiums or payments from those in the insurance program can shift responsibility to vulnerable households and communities and away from social institutions that may have previously aided reconstruction; in contrast, informal or public mechanisms, like remittances or reserve funds, share losses usually across family members and taxpayers. For insurance programs, it should be asked if the insured, themselves, pay the risk-estimated premium thus putting the full burden on their own at-risk communities (and at the same time providing incentives for them to reduce their risks). Alternatively, are there arrangements, like cross subsidies, that allocate this burden differently within the risk pool, or are there arrangements, like transfer payments, that allocate the burden at least partially to those outside the risk pool? 


\subsubsection{Equity Principles in the Compensation of Loss and Damage}

The essential question for the L\&D discussions is then "who pays the premium?" To address this question in Box 21.2 we distinguish three principles of fundamental importance for organising insurance arrangements, each principle building on a different view of equity. Private market-based insurance, unless it is subsidised from outside or within the pool, operates on the principle of mutuality and thus does not share losses beyond the at-risk insured community. Private insurers may deviate from the mutuality principle with premium cross-subsidies, e.g., by charging their wealthy, lower-risk clients higher premiums to make policies affordable to low-income clients in high-risk locations. Sometimes this means a flat or undifferentiated premium that helps high risk (and often less wealthy) clients and avoids the costs and administrative burdens associated with differentiated premiums. In some cases, regulation dictates how private insurers can set premiums, usually to safeguard affordability. In India, for example, commercial insurers are required to offer 'pro-poor' policies, which they finance by charging their wealthy clients a higher rate. Without these forms of subsidy in a mutuality-based system the policyholders, themselves, can expect (in the long term) to pay premiums that are approximately equivalent to their received claim payments (actuarially fair premiums), plus significant additional costs (loads shown in Fig. 21.2). Thus, in an insurance system based on mutuality, there is no reimbursement to the victims of disasters (on average) outside of what they, themselves, contribute in premiums; in other words, the at-risk community finances its own curative measures. This is an important and often misunderstood feature of the insurance mechanism, and arguably disqualifies commercial insurance as a curative measure as intended by the WIM.

Solidarity can take many forms, including subsidised or cross-subsidised premiums, reinsurance or other forms of assistance that reduce premiums paid by the most vulnerable. It is the fundamental principle underlying pre-disaster assistance and post-disaster humanitarian relief and reconstruction (see Schinko et al. 2018). Support can come from, among others, governments, NGOs, financial institutions or international development organisations. Indeed, almost all micro-insurance programs and macro-level pools operating in developing countries receive some type of donor or government support (Vivid Economics et al. 2016). Importantly, solidarity, in contrast to accountability, need not appeal to a causal relationship between historical greenhouse gas emissions and loss and damage, or culpability on the part of those providing support for insurance instruments. 


\section{Box 21.2 Three equity principles for organising insurance Mutuality}

Mutuality is at the core of the insurance concept, according to which the insured participate in a disaster pool according to their risk class (and pay a risk-based premium). The pool then pays those insured in accordance with the scale of their losses. Mutuality is the primary principle underlying private, market-based insurance; clients enter the pool usually voluntarily, and pay according to the best estimate of the risk they bring with them. While insured agents receive payments from the pool depending on their losses, in the long run (and on average) they pay their own reimbursement, and more, since the premium is based on expected loss plus the additional insurance loads shown in Fig. 21.2. According to this principle, there are no transfer payments within the pool or from outside the pool (Wilkie 1997).

\section{Solidarity}

Solidarity is a profoundly different concept in that losses are paid according to need, and contributions to the pool are not made fully in accordance with the risks that the applicants bring with them, but perhaps partly according to ability to pay, or just equally. Solidarity can result from cross subsidies among those in the pool. It can also take the form of payments by those not in the pool, for example, aid agencies can subsidise micro-insurance schemes. Importantly, solidarity is based on the concept of voluntary transfers for humanitarian or other grounds; there is no underlying notion of liability. The concept of solidarity thus corresponds to the concept of distributive justice discussed in Wallimann-Helmer et al. (2018).

\section{Accountability}

Accountability as a concept differentiates itself from the solidarity principle in one important aspect; here, it is motivated by a perceived ethical or legal obligation for compensating those experiencing climate-attributed losses and damages. Accountability links an actor's actions with outcomes, either causally or legally (Honoré 2010) where the allocation of responsibility is based on causation and (often but not always) fault or negligence. Being accountable not only means being responsible for climateattributed impacts and risks but also ultimately being answerable for them.

A far more controversial and potent principle to underlie support for insurance instruments is accountability for loss and damage, which mirrors the "polluter-pays principle" that is invoked across many environmental issues. Accountability invokes questions of attribution (James et al. 2018) as well as some degree of culpability or fault. Both can be difficult to assign to state and other actors since the science is not sufficiently precise to estimate increased risk of losses and damages due to emissions of greenhouse gases, and fault for emissions can be questioned due to historical knowledge and other factors (Burkett 2014). The assignment of accountability for losses and damages, and ultimately responsibility, has been understandably resisted because of fears of legal liability. Indeed, the Paris Agreement explicitly rejects that the treaty provide a basis for liability or compensation (Simlinger and Mayer 2018). Yet, as Lees (2016) argues, the refusal to contemplate liability should not lead to a refusal to contemplate the allocation of ethical responsibility-what he refers to as a responsibility allocation mechanism. Indeed, recognition of ethical responsibility, as 
differentiated from legal liability, may be necessary, if not essential, for motivating even voluntary support for insurance instruments on the scale contemplated by the L\&D discussions.

Principles of solidarity and accountability are strongly voiced in the Framework Convention on Climate Change (UNFCCC), which states that parties should act to protect the climate system "on the basis of equality and in accordance with their common but differentiated responsibilities and respective capabilities" (United Nations 1992). A fundamental element of this principle, which is restated in the preamble to the Paris Agreement, is the need to take account of the different circumstances, particularly each State's contribution to the problem and capacity to remedy it (Decision 3/CP.19). The WIM, likewise, refers to the need to take account of differentiated responsibility (accountability) for losses and damages (Lees 2016). The principles set out in the UNFCCC and Paris Agreement suggest that those bearing responsibility for losses and damages, and those most capable of addressing it, should bear some obligation to contribute to insurance premiums for climate-attributed risks in highly vulnerable countries. In fact, many developing country Parties and NGOs have advocated the accountability principle. The submission of CARE to the current WIM work plan is illustrative:

...(WIM) should apply principles of global equity, including taking into account a "polluter pays"-based approach to generating finance for addressing loss and damage from countries, companies and institutions who significantly contribute to the causes of climate change through fossil fuel emissions (CARE International 2017).

Invoking responsibility/accountability in the discourse on developed country support (but avoiding legal liability) changes the paradigm of post-disaster support from 'charity' to 'amends', which has significance in terms of allocating funds beyond humanitarian assistance budgets. Arguably, a responsibility-based discourse can change the motivation for assisting victims of climate-attributed impacts and risks - so essential to implementing the Paris Agreement and maintaining its voluntary, cooperation-focused approach (see chapter by Schinko et al. 2018).

\subsubsection{Experience of Micro-insurance for Equitably Allocating the Impacts and Risks Burden}

Almost without exception micro-insurance schemes that serve the resource-poor are
subsidised either by national taxpayer funds or, more often, by international donors,
international financial institutions, NGOs and official development assistance (Mech-
ler et al. 2006; Schäfer and Waters 2016). Few private insurers are optimistic about
the prospects of providing non-subsidised insurance to clients below the poverty
level (Swiss Re 2012).
As one example, India's National Agricultural Insurance Scheme (NAIS), globally
the largest micro-insurance crop program, targets mainly middle-income farmers and
is heavily subsidised by Indian taxpayers (Mechler et al. 2006). As another example,
the pro-poor R4 initiative discussed above is made possible by the significant support
it receives from NGOs and donors as well as its reliance on funds (in Ethiopia) 
from Ethiopia's Productive Safety Net Program and the World Food Programme. An innovative micro-insurance program for herders in Mongolia is affordable and viable to insurers due to its layered system of responsibility and payment, including herders (who retain small losses or the lowest risk layer), the private insurance industry (riskbased premium payments for the middle layer of risk) and taxpayers (for the highest risk layer). In addition to subsidies, micro-insurance is typically made affordable by greatly reducing the cover offered. A micro-insurance program in Bangladesh, Proshika, that insures savings against natural disasters limits claims to twice the amount in the client's savings account (Mechler et al. 2006). Similarly, a microinsurance project in Malawi was made affordable by limiting cover to the cost of the hybrid seeds, which protects the banks against defaults for their seed loans, but does not protect households against drought losses (Linnerooth-Bayer et al. 2009).

The extensive support for micro-insurance falls thus solidly under the insurance principle of solidarity, where contributions to the pool are made, not in accordance with the risks that applicants bring to the pool, but typically according to their ability to pay the premium. Climate-attributed impacts and risks will likely continue to be framed as a humanitarian issue invoking solidarity, and not as an issue invoking accountability or liability.

\subsubsection{Experience of Regional Insurance Pools for Equitably Sharing the Impacts and Risk Burden}

The question addressed in this section is to what extent the regional insurance pools (CCRIF, ARC and PCRAFI) provide their members with an equitable curative response to climate-attributed losses and damages, keeping in mind that the pools provide cover to governments, which in turn (and in varying degrees) provide postdisaster support to vulnerable households, farms and SMEs. By 'equitable' we again refer to the three principles relevant to insurance: mutuality, solidarity and accountability. We ask, thus, who pays the price for membership in the risk pools, and based on which equity principle?

All pools have received donor support, mostly through capitalisation, payment of operational expenses, direct premium support or capacity building. While the premiums are therefore less than would be required without outside support, in the case of ARC and CCRIF the relative premiums (the proportion each member country pays to the pool) tend to be based on risk levels (i.e., there are no cross subsidies). The pools are thus based on solidarity from the outside, but mutuality in determining the relative payments from members. For ARC, all insured countries pay premiums based on risk estimates, while for setting up and operating the pools support comes from donor organisations. In other words, donors contribute to reducing some of the loads on the insurance premium. ARC's non-profit mutual insurance company (not necessarily meaning the premiums are based on mutuality) is capitalised by financial and development institutions, including the German Development Bank and the UK Department for International Development (DFID), which means that premiums are indirectly supported through a solidarity principle. For ARC, thus, 
there are elements of mutuality in setting country-specific trigger points and caps, which largely determine premiums, and also elements of solidarity given substantial donor support.

The PCRAFI, in contrast, bases premiums largely on ability-to-pay of its member countries rather than a calculated risk. This means there are substantial cross subsidies across member states. In addition, multiple development partners and IDA credit have contributed to the establishment of the pool as well as to premium support. The PCRAFI is thus based primarily on the principle of solidarity in terms of both outside- and inside-pool support.

Interestingly the principle of accountability has not been invoked in justifying the contributions of the donor community to these systems, even though climate change is a concern to all regional pools. However, not surprising after the devastating 2017 Hurricanes Harvey and Irma, the attribution of the covered hazards to climatic change is under investigation for CCRIF and the other pools. More specifically, as an innovative proposition, ARC is setting up an Extreme Climate Facility (XCF) that would be capitalised by the international community if trends in extreme weather are found attributable to climate change (Wilcox 2014). Thus, the XCF can be considered a manifestation of climate change risk, although there is no direct discussion of this facility extracting payments based on greenhouse emissions from wealthy countries, and thus no direct appeal to the accountability principle.

\section{Box 21.3 The Extreme Climate Facility (XCF) of the African Risk Capacity (ARC) Function}

Additional financing for countries already managing their current weather risks through ARC.

\section{Data-driven modus operandi}

Payments to countries will be entirely data-driven over a 30 year period-if there is no significant increase in extreme events over current climatology, then no payment is made.

\section{Climate Adaptation}

Countries must use payments to invest in DRR or climate change adaption measures specified in pre-defined country level adaptation funds.

\section{Scale}

Payment size would increase with extreme event number and magnitude over and above a pre-specified threshold, corresponding to the degree of confidence that extreme events are increasing due to climate change.

\section{Action focus}

Leveraging ARC's existing infrastructure, $\mathrm{XCF}$ will ensure that countries and the international community properly monitor climate shocks and are financially prepared to undertake greater adaptation measures should their frequency and intensity increase. Source Wilcox (2014) 


\subsection{Summary: The Evolving Insurance Narrative}

This chapter has asked whether insurance instruments, and particularly microinsurance and regional insurance pools, can serve as a risk-reducing and equitable compensatory response to climate-attributed losses and damages from weather extremes occurring in developing countries, and consequently if insurance instruments can serve the preventative and curative targets of the WIM and the Paris Agreement? As background, the chapter recognises that insurance, by dealing exclusively with residual, sudden-onset event risks, can be only one part of the L\&D response.

The discussion has emphasised the substantial benefits of both micro-insurance programs and regional insurance pools: micro-insurance for providing post-disaster relief and reconstruction and also pre-disaster security (so important for adaptation and escaping poverty); regional insurance pools for decreasing the costs of reinsurance for governments and enabling early disbursement of emergency relief that saves lives, reduces distressed productive asset sales and mitigates disaster-induced poverty traps. The discussion has also emphasised the significant costs of insurance, noting that insured households and governments will on average pay considerably more for climate insurance than they expect to lose from extreme climate events.

Notwithstanding the benefits and costs, the discussion has examined insurance instruments for their role in meeting the curative and preventative aspirations for the WIM-equitably compensating for residual climate-attributed impacts providing strong incentives or directives for reducing risks. A main message from this discussion is that absent significant intervention in their design and implementation, insurance mechanisms as currently implemented will likely fall short of fully meeting WIM aspirations as (differently) expressed by developed and developing country Parties. This message is detailed in Table 21.3, which provides the mechanisms by which insurance can in principle support WIM responses.

Recent experience shows that with some important exceptions indemnity and parametric programs (mainly public-private partnerships), beyond pricing risk and reducing moral hazard, have few explicit incentives or requirements for risk reduction, even if their potential is promising. Reforming insurance programs for improved loss reduction can build on recent successful experiences, particularly evidence of significant risk-reduction activities on the part of public insurers compared to their private insurer counterparts, and innovations and developments in risk pricing and engineering, along with more targeted use of limits, deductibles and warranties. Still, as we witness in wealthy countries, progress will be slow and patchy without public and private commitment to shaping insurance systems such that they foster practices that lead to investment in disaster risk reduction practices.

A similar message emerges regarding the curative aspirations for the WIM. Insurance based on the principle of mutuality (typically private, market-based insurance), unless subsidised or otherwise supported, does not share risk beyond the at-risk insured community. There is thus no reimbursement of losses to the victims of disasters (on average) outside of what policyholders, themselves, contribute in premiums, which disqualifies mutuality-based insurance as a curative mechanism meeting vul- 


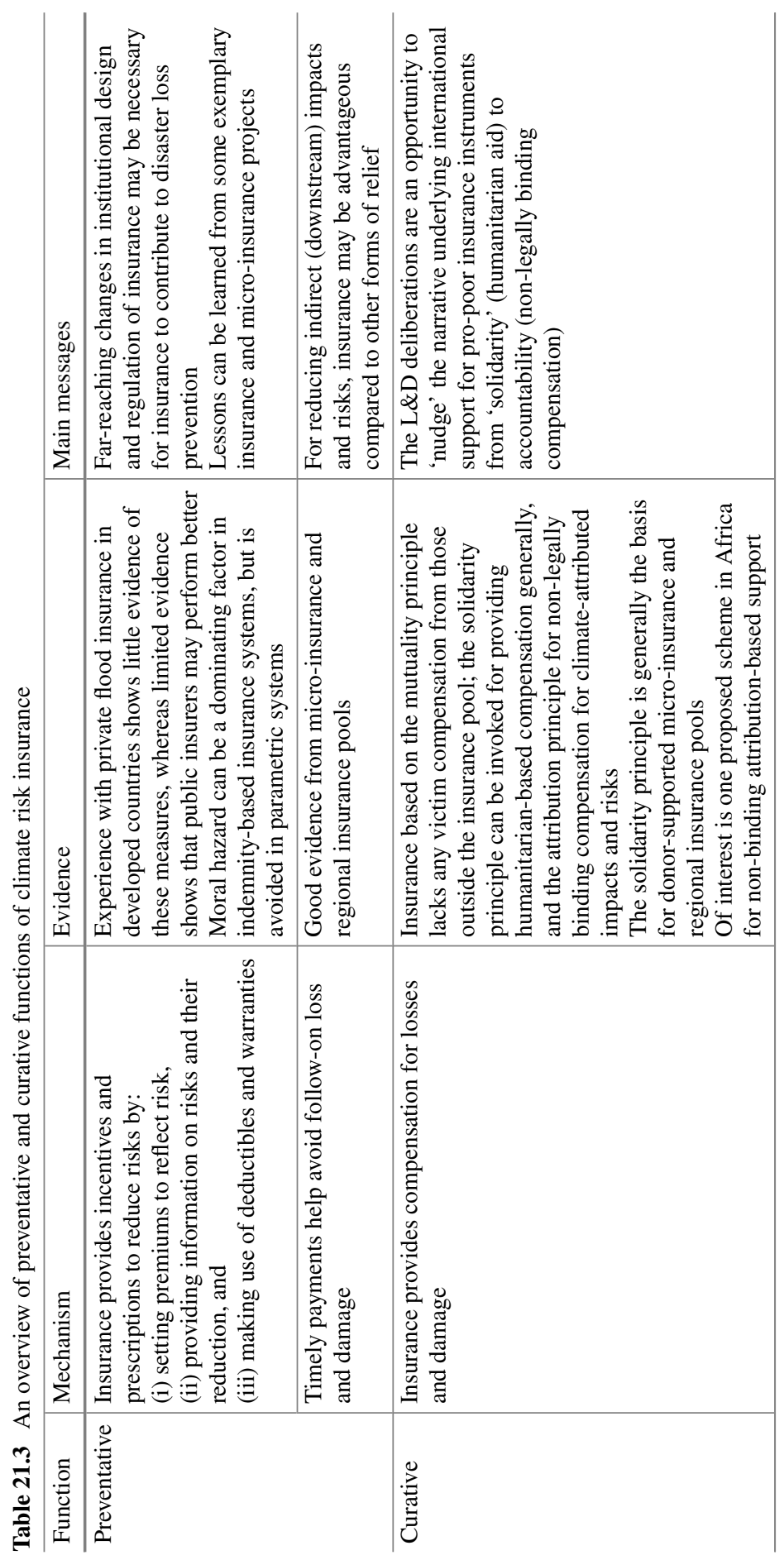


nerable country aspirations for the WIM. Mutuality, however, is not a feature of most donor-supported micro-insurance and regional insurance pools.

A challenge with the solidarity principle, if premiums are subsidised, is the lessened incentive for policyholders to reduce their risk. In meeting this challenge, international financial institutions, development agencies and other donors will need to reconcile the contending equity and preventative objectives in their support of climate insurance programs. This is foremost a challenge in designing "smart" insurance programs that are considered equitable and at the same time provide incentives or directives to their clients to reduce risks.

Two often cited success stories for insurance instruments serving the most vulnerable the African R4 micro-insurance program and the African Risk Capacity (ARC) regional insurance pool, go a long way in combining these goals. Neither is a commercial insurance enterprise; neither is (fully) characterised by risk-based premiums; and both are highly subsidised. The R4 program's success has been attributed in large part to its close connection with public safety net programs in the participating countries, and the ARC can attribute its success largely to its required disbursement plans. As evidence of extreme climate-attributed impacts and risks becomes more widely available and accepted, ARC's innovative XCF program may serve as a conduit for institutionalising donor support in the form of increased pool capitalisation.

The provision of support to regional insurance pools and micro-insurance programs continues to be framed as humanitarian aid, not invoking accountability or liability for climate-attributed loss and damage. Indeed, support for insurance programs has come mainly from development and financial organisations, such as the World Bank, national development partners, and international NGOs, with emphasis on the potential role of insurance in supporting poverty reduction in the face of climate and disaster risks. In other words, the narrative for support has been framed as a humanitarian and development issue.

The insurance discourse may, however, be changing. This is perhaps most apparent in discussions on the recent G7 Initiative on Climate Risk Insurance (InsuResilience), which has the ambitious goal of increasing access to direct or indirect climate insurance coverage for up to 400 million of the most vulnerable people in developing countries by 2020 (G7 2015; InsuResilience 2017). While InsuResilience does not officially commit to any specific equity principle, there are a number of voices that raise this aspect. One example is the Munich Climate Insurance Initiative (MCII), a close advisor to InsuResilience. MCII is forthright about the need to ground financial support in ethical claims of accountability and also capability. In the words of this NGO (whose members include insurers, NGOs and researchers), InsuResilience should provide technical and financial support to the set-up and maintenance of risk facilities and pools, the capitalisation of national and regional risk pools and other forms of co-financing premiums. This support should follow the principles of "capability, including sharing the risks imposed by climate change and responsibility for climate change impacts" (Schäfer and Waters 2016). The G7 initiative has thus unleashed a broad-ranging discussion on who should pay for insurance, sovereign risk transfer and social protection systems in light of climate change. In a commen- 
tary in Nature Climate Change, Surminski and colleagues (2016) explicitly raise this issue:

As the intensity and frequency of climate extremes increase, is it fair to shift responsibility on to those who are the least responsible for climate change, the least able to shoulder the premiums, and in many cases the least able to reduce their losses?

As the recent G20/V20 Global Partnership on InsuResilience (launched at COP23) shows, the need for donor support is increasingly accepted by the development finance community. Importantly, this financial support should be 'smart', understood as reliable, flexible, minimise incentive distortions, and make the recipients aware of the true cost of the covered risk (Schäfer and Waters 2016). In this way, subsidised insurance can be linked to risk reduction (Hill et al. 2014; Vivid Economics et al. 2016). As a concrete proposal, Kunreuther and Michel-Kerjan (2009) have argued that the subsidy should take the form of an insurance voucher so that the recipient is aware of the unsubsidised premium. In addition, donor support should be conditional by requiring contingency and disbursement plans (Schäfer and Waters 2016; Surminski et al. 2016). A suggestion recently iterated by Schäfer and Waters (2016) is that smart premium support should cover only part of the premium, for example, only the markup (the risk and expense loads) while the beneficiary pays just the actuarial fair value or pure premium.

The message this chapter holds for the L\&D discussions is to advise caution about relying on the market, alone, to provide insurance for fulfilling aspirations for the WIM, and to recognise the criticality of international and public intervention in climate insurance provision. Interventions can include subsidies, technical assistance, capitalisation of insurance programs, provision of reinsurance and other types of support that make insurance affordable to resource-poor and climate-sensitive clients; interventions can also enable regulatory regimes and public-private arrangements that exploit the potential for insurance to genuinely catalyse risk reduction far beyond what has been accomplished by commercial insurers thus far. It is therefore important to continue developing "smart" regional or national programs that explicitly combine insurance with loss prevention and that address the emerging equity issues as climate change impacts the most vulnerable and least responsible. The WIM Executive Committee continues to contemplate subsidies for pro-poor insurance programs (Executive Committee to the WIM 2016), a measure that will grow in importance if the insurance narrative continues to evolve from solidarity-based humanitarian assistance to accountability for climate-attributed impacts.

\section{References}

Alliance of Small Island States (AOSIS) (2008) Proposal to the AWG-LCA multi-window mechanism to address loss and damage from climate change impacts

Arent DJ, Tol RSJ, Faust E, Hella JP, Kumar S, Strzepek KM, Tóth FL, Yan D (2014) Key economic sectors and services. In: Field CB, Barros VR, Dokken DJ, Mach KJ, Mastrandrea MD, Bilir TE, Chatterjee M, Ebi KL, Estrada YO, Genova RC, Girma B, Kissel ES, Levy AN, MacCracken S, 
Mastrandrea PR, White LL (eds) Climate change 2014: impacts, adaptation, and vulnerability. Part A: global and sectoral aspects. Contribution of working group II to the fifth assessment report of the intergovernmental panel on climate change. Cambridge University Press, Cambridge, United Kingdom and New York, NY, USA, pp 659-708

ARTEMIS (2017a) CCRIF parametric payouts on Hurricane Irma reach $\$ 31.2 \mathrm{~m}$, Sept 20. http://www.artemis.bm/blog/2017/09/20/ccrif-parametric-payouts-on-hurricane-irma-reach31-2m/. Accessed 30 Sep 2017

ARTEMIS (2017b) AIR puts M8.1 Chiapas, Mexico quake industry loss at up to $\$ 1.13 \mathrm{bn}$, Sept. 20. http://www.artemis.bm/blog/2017/09/20/air-puts-m8-1-chiapas-mexico-quake-industr y-loss-at-up-to-1-13bn/

Botzen WJW (2013) Managing extreme climate change risks through insurance. Cambridge University Press, Cambridge

Bouwer LM (2018) Observed and projected impacts from extreme weather events: implications for loss and damage. In: Mechler R, Bouwer L, Schinko T, Surminski S, Linnerooth-Bayer J (eds) Loss and damage from climate change. Concepts, methods and policy options. Springer, Cham, pp 63-82

Brainard L (2008) What is the role of insurance in economic development?. Zurich Government and Industry Affairs thought leadership series, Zurich Insurance, Zurich

Burkett M (2014) Loss and damage. Clim Law 4(1-2):119-130

Calliari E, Surminski S, Mysiak J (2018) Politics of (and behind) the UNFCCC's loss and damage mechanism. In: Mechler R, Bouwer L, Schinko T, Surminski S, Linnerooth-Bayer J (eds) Loss and damage from climate change. Concepts, methods and policy options. Springer, Cham, pp $155-178$

Cardenas V, Hochrainer S, Mechler R, Pflug G, Linnerooth-Bayer J (2007) Sovereign financial disaster risk management: the case of Mexico. Environ Hazards 7:40-53

CARE International (2017) Submission on the 5 year work plan of the Warsaw International Mechanism for Loss and Damage, 28 February. http://careclimatechange.org/wp-content/uploads/201 7/03/CARE-Submission-on-the-5year-work-plan-of-the-WIM.pdf

Chambwera M, Heal G, Dubeux C, Hallegatte S, Leclerc L, Markandya A, McCarl BA, Mechler R, Neumann JE (2014) Economics of adaptation. In: Field CB, Barros VR, Dokken DJ, Mach KJ, Mastrandrea MD, Bilir TE, Chatterjee M, Ebi KL, Estrada YO, Genova RC, Girma B, Kissel ES, Levy AN, MacCracken S, Mastrandrea PR, White LL (eds) Climate change 2014: impacts, adaptation, and vulnerability. Part A: global and sectoral aspects. contribution of working group II to the fifth assessment report of the intergovernmental panel on climate change. Cambridge University Press, Cambridge, United Kingdom and New York, NY, USA, pp 945-977

Clarke D, Hill R (2013) Cost-benefit analysis of the African risk capacity facility, IFPRI Discussion Paper 01292, International Food Policy Research Institute, Washington DC, USA

Clarke D, Dercon S (2016) Dull disasters. How planning ahead will make a difference. Oxford University Press, Oxford

Cohen M, Sebstad J (2003) Reducing vulnerability: the demand for microfinance. A synthesis report. Micro Save-Africa, Nairobi

Crichton D (2008) Role of insurance in reducing flood risk. The Geneva Papers on Risk and Insurance Issues and Practice, 33:117-132. https://doi.org/10.1057/palgrave.gpp.2510151

Cummins J, Mahul O (2009) Catastrophe risk financing in developing countries: principles for public intervention—overview. Washington, DC, The World Bank. http://gfdrr.org/docs/Track-I I_Catrisk_financing_Overview_booklet.pdf. Accessed 27 May 2017

G7 (2015) Leaders' Declaration G7 Summit, 7-8 June 2015. Available from https://sustainabledev elopment.un.org/content/documents/7320LEADERS\%20STATEMENT_FINAL_CLEAN.pdf. Accessed 27 Jan 2017

Ghesquiere F, Mahul O (2010) Financial protection of the state against natural disasters: a primer. Policy Research working paper WPS 5429. World Bank, Washington, DC

Hallegatte S, Vogt-Schilbac, Bangalore M, Rozenberg J (2016) Unbreakable: building the resilience of the poor in the face of natural disasters. Climate change and development series. Washington, 
D.C.: World Bank Group. http://documents.worldbank.org/curated/en/512241480487839624/Un breakable-building-the-resilience-of-the-poor-in-the-face-of-natural-disasters. Accessed 30 May 2017

Hazell P, Anderson J, Balzer N, Hastrup Clemmensen A, Hess U, Rispoli F (2010) The potential for scale and sustainability in weather index insurance for agriculture and rural livelihoods. International Fund for Agricultural Development and World Food Programme, Rome

Heltberg R, Siegel P, Jorgensen S (2009) Addressing human vulnerability to climate change: towards a 'No-Regrets' approach. Glob Environ Change 19(1):89-99

Heltberg, R, Siegel P, Jorgensen S (2009b) Social policies for adaptation to climate change. In: Mearns R, Norton A (eds) Social dimensions of climate change: equity and vulnerability in a warming world. Washington, DC, The World Bank

Hill VR, Gajate-Garrido G, Phily C, Dalal A (2014) Using subsidies for inclusive insurance: lessons from agriculture and health. Microinsurance Paper No. 29. International Labour Organization. http://www.impactinsurance.org/sites/default/files/MP29.pdf. Accessed 27 May 2017

Hochrainer-Stigler S, Linnerooth-Bayer J, Lorant A (2017) The European union solidarity fund: an assessment of its recent reforms. Mitig Adapt Strat Glob Change 22(4):547-563. https://doi.org/ $10.1007 / \mathrm{s} 11027-015-9687-3$

Honoré A (2010) Causation in the law. In: Zalta EN (ed) Stanford encyclopedia of philosophy. Stanford University (online), Stanford, pp 1-22

INC (Intergovernmental Negotiating Committee for a Framework Convention on Climate Change) (1991) Preparation of a Framework Convention on Climate Change. Set of informal papers provided by delegations, related to the preparation of a Framework Convention on Climate Change. Addendum 3, A/AC.237/Misc.1/Add.3 A/AC.2, United Nations Office at Geneva

InsuResilience (2017) Joint Statement on the InsuResilience Global Partnership. 14 November 2017. Bonn

James, RA, Jones, RG, Boyd, E, Young, HR, Otto, FEL, Huggel, C and JS Fuglestvedt (2018) Attribution: how is it relevant for loss and damage policy and practice? In: Mechler R, Bouwer L, Schinko T, Surminski S, Linnerooth-Bayer J (eds) Loss and damage from climate change. Concepts, methods and policy options. Springer, Cham, pp 113-154

Kunreuther H (1996) Mitigating disaster losses through insurance. J Risk Uncertainty 12:171-187. https://doi.org/10.1007/BF00055792

Kunreuther H (1998) Insurability conditions and the supply of coverage. In: Kunreuther H, Roth RJ (eds) Paying the price: the status and role of insurance against natural disasters in the United States. Washington DC, Joseph Henry Press, pp 17-50

Kunreuther H, Michel-Kerjan E (2009) At war with the weather: managing large-scale risks in a New Era of catastrophes. MIT Press Books, Cambridge, MA

Lees E (2016) Responsibility and liability for climate loss and damage after Paris. Clim Policy 17(1):59-70

Linnerooth-Bayer J, Mace MJ, Verheyen R (2003) Insurance-related actions and risk assessment in the context of the UNFCCC. Background paper for UNFCCC workshop on Insurance-related Actions and Risk Assessment in the Framework of the UNFCCC, 11-15 May 2003, Bonn, Germany

Linnerooth-Bayer J, Mechler R, Bals C (2010) Insurance as part of a climate strategy. In: Hulme M, Neufeldt $\mathrm{H}$ (eds) Making climate change work for us: European perspectives on adaptation and mitigation strategies. Cambridge University Press, Cambridge

Linnerooth-Bayer J, Hochrainer-Stigler S, Mechler R (2012) Mechanisms for financing the costs of disasters, Foresight project 'Reducing Risks of Future Disasters: Priorities for Decision Makers', UK Government Office of Science, London. http://www.bis.gov.uk/assets/foresight/docs/redu cing-risk-management/supporting-evidence/12-1308-mechanisms-financing-costs-of-disasters. pdf. Accessed 5 Feb 2018

Linnerooth-Bayer J, Suarez P, Victor M, Mechler R (2009). Drought insurance for subsistence farmers in Malawi. Nat Hazards Observer 33(5):1-8 
Lorant A, Linnerooth-Bayer J, Hanger S Insurance and climate risk reduction: from concept to practice? IIASA Working Paper, Laxenburg, Austria, forthcoming

Mace M, Verheyen R (2016) Loss, damage and responsibility after COP21: all options open for the paris agreement. Rev Eur Compar Int Environ Law 25(2):197-214

Mechler R, Linnerooth-Bayer J, Peppiatt D (2006) Disaster insurance for the poor? A ProVention/IIASA study. A review of microinsurance for natural disaster risks in developing countries. Provention consortium, Geneva

Mechler R, Bouwer LM, Linnerooth-Bayer J, Hochrainer-Stigler S, Aerts JCJH, Surminski S, Williges K (2014) Managing unnatural disaster risk from climate extremes. Nat Clim Change 4(4):235-237. https://doi.org/10.1038/nclimate2137

Mechler R, Schinko T (2016) Identifying the policy space for climate loss and damage. Science 354(6310):290-292. https://doi.org/10.1126/science.aag2514

Mechler R (2004) natural disaster risk management and financing disaster losses in developing countries. Verlag für Versicherungswirtschaft, Karlsruhe

Mechler R et al (2018) Science for loss and damage. Findings and propositions. In: Mechler R, Bouwer L, Schinko T, Surminski S, Linnerooth-Bayer J (eds) Loss and damage from climate change. Concepts, methods and policy options. Springer, Cham, pp 3-37

Moftakhari HR, Agha Kouchak A, Sanders BF, Matthew RA (2017) Cumulative hazard: the case of nuisance flooding, Earth's Future, 5. https://doi.org/10.1002/2016ef000494

Molini V, Keyzer M, van den Boom B, Zant W (2007) Creating safety nets through semi-parametric index-based insurance: a simulation for Northern Ghana, MyIdeas. https://ideas.repec.org/p/ags/ eaa101/9263.html. Accessed 27 Jan 20171

Munich Climate Insurance Initiative (MCII) (2008). Insurance Instruments for Adapting to Climate Risks: A proposal for the Bali Action Plan, Version 2.0. MCII Submission to the 4th session of the Ad Hoc Working Group on Long-Term Cooperative Action under the Convention (AWG-LCA 3). Poznan 1-13 December, 2008. www.climate-insurance.org/upload/pdf/MCII_submission_P oznan.pdf. Accessed 27 May 2017

Newsham A, Davies M, Béné C (2011) Making social protection work for pro-poor disaster risk reduction and climate change adaptation. background paper. Institute of Development Studies, Brighton

OMTRIX (2005) A fund to support micro-finance institutions in case of emergency (ELF). Costa Rico, San Jose

Oxfam International Four simple strategies which are helping Ethiopian farmers adapt to climate change. https://www.oxfam.org/en/ethiopia/four-simple-strategies-whichare-helpingethiopian-f armers-adapt-climate-change. Accessed 6 Oct 2017

Pollner J (2000) Managing catastrophic risks using alternative risk financing \& insurance pooling mechanisms. World Bank, Washington DC

Re Swiss (2012) Microinsurance-risk protection for 4 billion people, SIGMA 6/2012. Swiss Re, Zurich

Schäfer L, Waters E (2016) Climate risk insurance for the poor and vulnerable. How to effectively implement the pro-poor focus of InsuResilience. http://www.climateinsurance.org/fileadmin $/ \mathrm{m}$ cii/documents/MCII_2016_CRI_for_the_Poor_and_Vulnerable_fullstudy_lo-res.pdf. Accessed 20 March 2017

Schäfer, L, Warner, K, Kreft S (2018) Exploring and managing adaptation frontiers with climate risk insurance. In: Mechler R, Bouwer L, Schinko T, Surminski S, Linnerooth-Bayer J (eds) Loss and damage from climate change. Concepts, methods and policy options. Springer, Cham, pp 317-341

Schinko T, Mechler R, Hochrainer-Stigler S (2018) The risk and policy space for loss and damage: integrating notions of distributive and compensatory justice with comprehensive climate risk management. In: Mechler R, Bouwer L, Schinko T, Surminski S, Linnerooth-Bayer J (eds) Loss and damage from climate change. Concepts, methods and policy options. Springer, Cham, pp $83-110$ 
Schwarze R, Croonenbroeck C (2017) Economies of integrated risk management? An empirical analysis of the Swiss public insurance approach to natural hazard prevention. Econ Disaster Clim Change 1:167-178

Simlinger F, Mayer B (2018) Legal responses to climate change induced loss and damage. In: Mechler R, Bouwer L, Schinko T, Surminski S, Linnerooth-Bayer J (eds) Loss and damage from climate change. Concepts, methods and policy options. Springer, Cham, pp 179-203

Surminski S (2014) The role of insurance in reducing direct risk: the case of flood insurance. Int Rev Environ Res Econ 7(3-4):241-278

Surminski S, Eldridge J (2015) Flood insurance in England: an assessment of the current and newly proposed insurance scheme in the context of rising flood risk. J Flood Risk Manag

Surminski S, Bouwer LM, Linnerooth-Bayer J (2016) How insurance can support climate resilience. Nat Clim Change 6:333-334. https://doi.org/10.1038/nclimate2979

Swiss Re (2015) Natural catastrophes and man-made disasters in 2013, Sigma No 1/2014

UNFCCC (2008) Ideas and proposals on the elements contained in paragraph 1 of the Bali Action Plan Submissions from Parties, Addendum, Part I. http://unfccc.int/resource/docs/2008/awglca 4/eng/misc05a02p01.pdf. Accessed 5 Feb 2018

UNFCCC (2012) A literature review on the topics in the context of thematic area 2 of the work programme on loss and damage: a range of approaches to address loss and damage associated with the adverse effects of climate change note by the secretariat. Bonn, Germany

UNFCCC (2014) Decision 2/CP.20, paragraph 1. https://unfccc.int/files/bodies/election_and_me mbership/application/pdf/decision_2_cp20_loss_and_damage_committee.pdf. Accessed 27 Jan 2017

UNFCCC (2015) Paris Agreement. http://unfccc.int/files/essential_background/convention/applic ation/pdf/english_paris_agreement.pdf. Accessed 24 June 2017

UNFCCC (2016) FCCC/SB/2016/3. http://unfccc.int/resource/docs/2016/sb/eng/03.pdf. Accessed 27 Jan 2017

UNISDR (2017) Caribbean Catastrophe Risk Insurance Facility, the (CCRIF SPC), Prevention Web, http://www.ccrif.org. Accessed 5 Feb 2018

United Nations (1992) United Nations Framework Convention on Climate Change, New York

United Nations Office for Disaster Risk Reduction (UNISDR) (2017) Terminology. https://www.u nisdr.org/we/inform/terminology. Accessed 4 Jun 2017

Vaughan E, Vaughan T (2008) The fundamentals of risk and insurance. Wiley, New Jersey

Vellinga PV, Mills E, Bowers L, Berz G, Huq S, Kozak, L, Palutikod J, Schanzenbacher, Soler G, Dlugolecki A (2001) Insurance and other financial services. Climate change 2001: impacts, vulnerability, and adaptation. Working group II. none: none.--Report Number: LBNL-47924

Vivid Economics, Surminski Consulting and Callund Consulting (2016) FINAL REPORT: understanding the role of publicly funded premium subsidies in disaster risk insurance in developing countries. UK Department for International Development

von Peter G, von Dahlen S, Saxena S (2012) Unmitigated disasters? New evidence on the macroeconomic cost of natural catastrophes. BIS Working Papers No 394. Bank for International Settlements

von Ungern-Sternberg T (1996) The limits of competition: housing insurance in Switzerland. Eur Econ Rev 40(3-5):1111-1121

Wallimann-Helmer I, Meyer L, Mintz-Woo K, Schinko T, Serdeczny O (2018) The ethical challenges in the context of climate loss and damage. In: Mechler R, Bouwer L, Schinko T, Surminski S, Linnerooth-Bayer J (eds) Loss and damage from climate change. Concepts, methods and policy options. Springer, Cham, pp 39-62

Warner K, Ranger N, Surminski S, Arnold M, Linnnerooth-Bayer J, Michel-Kerjan E, Kovacs P, Herweijer C (2009) Adaptation to climate change: linking disaster risk reduction and insurance, United Nations International Strategy for Disaster Reduction Secretariat (UNISDR), Geneva. http://www.microinsuranceconference.com/dms/MRS/Documents/Microinsurance/MI C_Agriculture_Bibliography/9654_linkingdrrinsurance.pdf. Accessed 27 Jan 2017 
Warner K, van der Geest K, Kreft S, Huq S, Kusters K, de Sherbinin A (2012) Evidence from the frontlines of climate change: Loss and damage to communities despite coping and adaptation. Loss and Damage in Vulnerable Countries Initiative. Policy Report. Report No. 9. Bonn: United Nations University Institute for Environment and Human Security (UNU-EHS)

Wilcox R (2014) ARC Extreme Climate Facility (XCF). Presentation at 5th International Disaster \& Risk Conference IDRC Davos

Wilkie D (1997) Mutuality and solidarity: assessing risks and sharing losses. Philos Trans Roy Soc London B: Biol Sci Lond B 352(1357):1039-1044. https://doi.org/10.1098/rstb.1997.0082

WIM Executive Committee of the Warsaw International Mechanism (2016) Submission to the Standing Committee on Finance (SCF) for inputs related to its 2016 fourth forum on "financial instruments that address the risks of loss and damage associated with the adverse effects of climate change". http://unfccc.int/adaptation/workstreams/loss_and_damage/items/8805.php

World Bank (2016) Migration and Remittances Factbook 2016, World Bank Group's Global Knowledge Partnership on Migration and Development (KNOMAD) initiative: Washington D.C

World Bank (2017) PCRAFI Facility: phase II: enhancing the financial resilience of Pacific island Countries against natural disaster and climate risk, Global Facility for Disaster Risk Reduction http://pubdocs.worldbank.org/en/178911475802966585/PCRAFI-4-pager-web.pdf. Accessed 5 Dec 2017

World Food Programme (2017) The R4 Rural Resilience Initiative. https://www.wfp.org/climatec hange/initiatives/r4-rural-resilience-initiative

World Food Programme and Oxfam America (2016) Joint Submission by the World Food Programme and Oxfam International to the UNFCCC Standing Committee on Finance.https://unfccc.int/files/cooperation_and_support/financial_mechanism/standing_comm ittee/application/pdf/scf_forum_joint_oxfam_wfp_submission_2_29_2016.pdf. Accessed 20 Mar 2017

Open Access This chapter is licensed under the terms of the Creative Commons Attribution 4.0 International License (http://creativecommons.org/licenses/by/4.0/), which permits use, sharing, adaptation, distribution and reproduction in any medium or format, as long as you give appropriate credit to the original author(s) and the source, provide a link to the Creative Commons license and indicate if changes were made.

The images or other third party material in this chapter are included in the chapter's Creative Commons license, unless indicated otherwise in a credit line to the material. If material is not included in the chapter's Creative Commons license and your intended use is not permitted by statutory regulation or exceeds the permitted use, you will need to obtain permission directly from the copyright holder. 